\title{
内面研削における砥石と工作物の熱変形挙動から考察した 形状創成機構の研究*
}

\author{
中 島 利 勝** 塚 本 真 也** 池上 直 久***
}

Behavior of Thermal Deformations of Wheel and Workpiece and Form Generation Mechanism in Internal Grinding Process

Toshikatsu Nakajima, Shinya Tsukamoto and Naohisa Ikegami

\begin{abstract}
In this report in order to make clear the form generation mechanism in the internal plunge grinding process, the thermal deformations of wheel and workpiece are measured with both workpiece width and grinding time. Main conclusions obtained are as follows: (1) In the internal plunge grinding, by contrast to the surface or external grinding, the workpiece surface expands with the thermal deformation in the opposite direction of wheel surface. (2) The ground workpiece profile becomes an extremely concave profile, because the wheel surface expands just like a barrel shape due to the thermal deformation of wheel. (3) In contraction process of the thermal deformation of workpiece the concavity decreases but after grinding the concavity is left as an error of surface profile.

Key words: internal plunge grinding, form generation mechanism, thermal deformation of wheel, thermal deformation of workpiece, concave profile, contraction process, workpiece profile
\end{abstract}

\section{1. 緒言}

内面プランジ研削の形状創成機構を砥石と工作物の熱変形挙 動から検討した研究は，現在までのところ報告されていない． これとは対照的に，平面研削では中野氏 ${ }^{12)}$, 横山氏 ${ }^{3)}$, 奥山

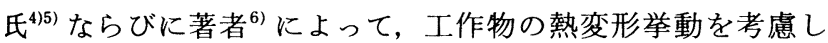
た形状創成機構に関する詳細かつ緻密な体系的研究がすでに完 成されている. 平面研削のこれら研究成果が内面プランジ研削 にもそのまま適用できるならば，本論文で内面プランジ研削の 形状創成機構を解析しても価值ある新知見が発見できる可能性 は低い。

そこで図 1 に示す内面プランジ研削に批いて，工作物断面を タイコ形状に創成するメカニズムが，平面研削での工作物の熱 変形挙動から合理的に類推できるか否かを，まず先決問題とし て検討してみる. 砥石と工作物との干渉領域に打ける発生研削 熱は工作物全体に拡散し, 半径方向 $r$ に対して $\theta_{\mathrm{w}}(r)$ の温度 分布だけ工作物を昇温させていると仮定しょう，平面研削の場 合と同様に，この $\theta_{\mathrm{w}}(r)$ による工作物の熱変形量 $d_{\theta \mathrm{w}}(b)$ は, 内径 $r_{\mathrm{a}}$ が砥石面へ近付く方向，すなわち図中の工作物の実測 断面から太い実線の位置まで膨張していると考える.しかも， 工作物両端は冷却されやすいため, 幅中央部で最大となるよう な熱変形量 $d_{\theta \mathrm{w}}(b)$ が分布するであろらことは容易に推測でき る.さらに，砥石面プロフィルの実測面の段差，すなわち工作 物と干渉した砥石面と砥石両端の研削に関与していない面との 段差からわかるように砥石摩耗量 $d_{0}(b)$ はほぼ均一に進行し ているので，研削中の工作物断面は直線的なテーパ形状に創成 されるはずである．この時点で研削を中断すると，熱変形量 $d_{\theta \mathrm{w}}(b)$ だけ工作物内径 $r_{\mathrm{a}}$ は砥石面から離れる方向へ収縮し, 幅中央部と両端との収縮量の差が中凹量 $\delta$ として残存する結 果, 工作物の断面形状が図示のようにタイコ状に創成されるの

\footnotetext{
* 原稿受付 平成 6 年 4 月 6 H

** 正会員岡山大学工学部 (岡山市津島中 3-1-1)

*** 学生会員 岡山大学大学院
}

である.

内面プランジ研削のこの形状創成理論は一見，合理的で矛盾 点は存在していない，と判断されるかもしれない。ところが, 熱応力を考慮した材料力学の解析 ${ }^{7) 8)}$ では, 図 1 の厚板円筒形 状の工作物に $\theta_{\mathrm{w}}(r)$ の温度分布を与えると, 前述の膨張方向 とは正反対に内径 $r_{\mathrm{a}}$ が増加する方向，つまり砥石面から離れ る方向へ膨張することは周知の事実だ，とされている. これに よると, 平面研削の場合とは全く異なる熱変形挙動で, 内面プ ランジ研削の工作物形状は創成されている可能性が高い.

そこで, 本研究では工作物の熱変形量だけでなく, 砥石の熱 変形量も具体的に実測し, 両者の熱変形挙動の観点から内面プ ランジ研削の形状創成機構を解明しょうとするものである.

\section{2. 砥石と工作物の熱変形量の測定方法}

図 2 に砥石と工作物の熱変形量の測定システムを示す．砥石 熱変形量の測定方法としては，鍵和田氏が開発したブレード転 写法 ${ }^{9)}$ とレーザ変位計による非接触走査形半径比較法 ${ }^{10)}$ ならび に著者の複回路差圧式空気マイクロメータ法 ${ }^{11)}$ が報告されて いる. ところが, 本実験の内面プランジ研削では工作物内径と

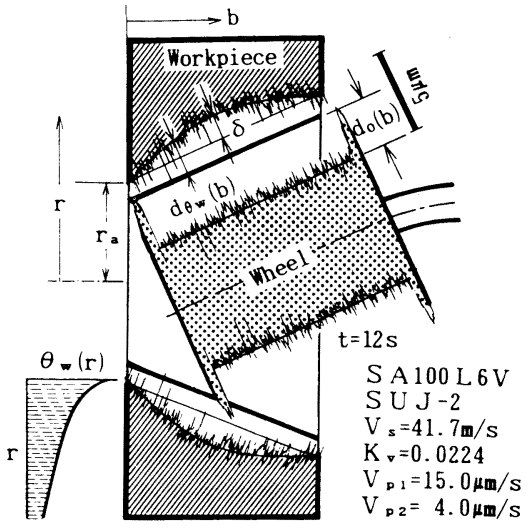

Fig. 1 Profiles of wheel and workpiece surface after internal plunge grinding 


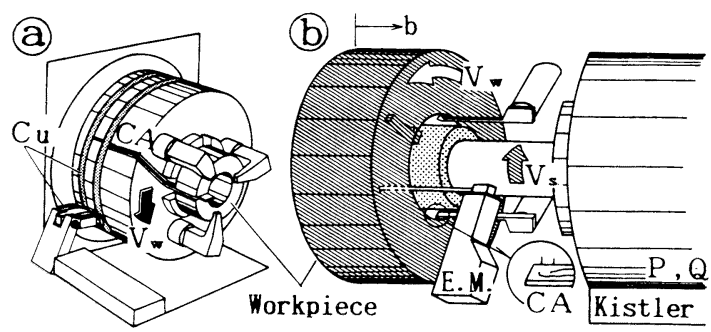

Fig. 2 Measuring system of thermal deformations of wheel $d_{\theta \mathrm{S}}(b)$ and workpiece $d_{\theta \mathrm{w}}(b)$

砥石外径の差が $5.0 \mathrm{~mm}$ しかないため,レーザ変位計や空気マ イクロメータなどのセンサを両者の間隙に設置することは非常 に困難である．そこで，ブレード転写法と類似の計測法を採用 することにした。すなわち，図 (b) の作物の形成溝にアクリ ル板を挿入し，このアクリル板に転写した研削中と研削後の砥 石面プロフィルを比較することによって砥石熱変形量を決定し た。ただし，砥石熱変形量を厳密に求めるためにはアクリル板 の熱膨張量を同定して扣くことが必要となる. それには, 図 (a)の CA（クロメルーアルメル）熱電対と $\mathrm{Cu}$ 薄板で構成した スリップリングを主軸円筒面上に試作し，アクリル板の半径方 向の温度分布を計測することで，この熱膨張量を算出してい る.

一方，工作物熱変形の測定にはホイールヘッド急速後退法 ${ }^{7)}$ を適用し，図中の E. M. で示すテュ式電気マイクロメータで検 出した. この電気マイクロメータを幅力向 $b$ 一移動させて, 各位置の工作物熱変形量と公称寸法生成量 ${ }^{7}$ を測定するととも に, 定寸装置で別の位置の公称寸法生成量を同時に出力させる ことも可能である. さらに，拡大図に示すように定寸装置の一 方のアームを CA 熱電対で作製した接触式温度センサ ${ }^{12) 13)}$ と交 換することで, 工作物の表面温度も計測している．また，研削 背分力 $P$, 主分力 $Q$ はホイールヘッド下部に組込んだ水晶式 圧電型工具動力計で検出した。

なお，内面研削の現場では既に複数段研削が常用されている ため, 実験はその基本型である 2 段プランジ研削方式で行っ た．その他の実験条件は以下に示すと扣りである.

試験機：CNC 内面研削盤 T-11 C 12

$$
\text { (トーヨーエイテック(株)製) }
$$

1 段プランジ速度： $V_{\mathrm{p} 1}=15.0 \mu \mathrm{m} / \mathrm{s}$ （研削時間 $t<11 \mathrm{~s}$ )

2 段プランジ速度： $V_{\mathrm{p} 2}=4.0 \mu \mathrm{m} / \mathrm{s}(11 \leqq t<19 \mathrm{~s})$

研削砥石：SA $100 \mathrm{~L} 6 \mathrm{~V}(\phi 21.0 \times 28 \mathrm{~mm})$

工作物: SUJ-2 $\left(2 r_{\mathrm{a}}=\phi 26.0 \mathrm{~mm} \times B=25 \mathrm{~mm}\right), \mathrm{HV}=804$ 砥石周速度： $V_{\mathrm{s}}=41.70 \mathrm{~m} / \mathrm{s}$

工作物周速度 : $V_{\mathrm{w}}=0.934 \mathrm{~m} / \mathrm{s}$

システム剛性 : $k_{\mathrm{sy}}=4.11 \mathrm{~N} / \mu \mathrm{m}$ （砥石幅中央部での值）

ドレッシング条件：切込み $20 \mu \mathrm{m} \times$ 送り $0.045 \mathrm{~mm} / \mathrm{rev}$. of G. W.

研削液：W 2 種 1 号の 80 倍希釈, 流量 $=8.8 \mathrm{l} / \mathrm{min}$

\section{3. 内面プランジ研削における砥石と工作物 の熱变形挙動}

図 3 に, 幅中央部 $B / 2$ に打 の測定例を示す．工作物の回転と研削液の注入を継続させたま ま，砥石だけを左下のモデル図の干渉位置で急速後退させる と, その瞬間から (a) の枠内に示す公称寸法生成量 $R(B / 2)$ は, $d_{\theta \mathrm{w}}(B / 2)$ の熱変形量を収縮させながら減少し始める.こ

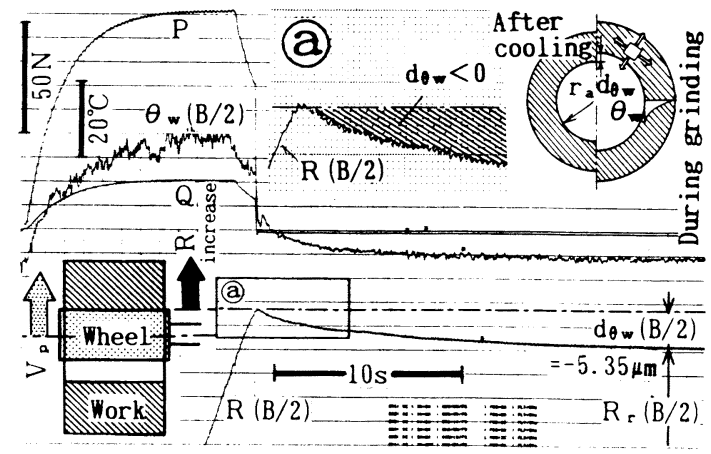

Fig. 3 A measured example of thermal deformation of work piece $d_{\theta \mathrm{w}}(B / 2)$ at middle of work width
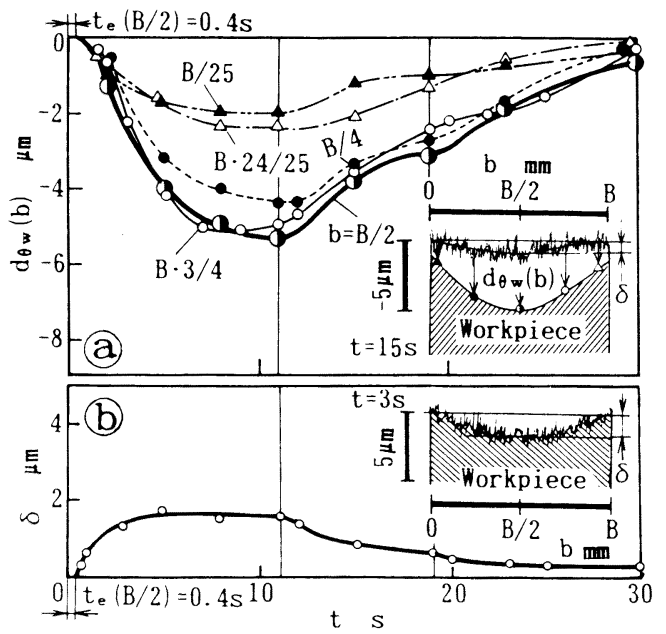

Fig. 4 Variations of thermal deformation of workpiece $d_{\theta \mathrm{W}}(b)$ and concave of workpiece profile $\delta$

こで注目すべきは, 収縮後の央寸法生成量 ${ }^{7)} R_{\mathrm{r}}(B / 2)$ が砥石 離脱時の公称寸法生成量 $R(B / 2)$ よりも小さくなっているこ とである. この測定結果から, 内面プランジ研削では砥石面か ら離れる方向すなわち工作物の内径 $r_{\mathrm{a}}$ を増加させる方向へ熱

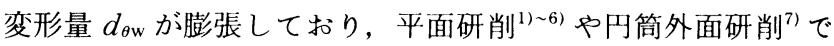
の工作物の膨張方向とは全く正反対であることがわかる.

本実験の図 3 で工作物の熱変形挙動を丰験的に初めて発見し た意義は決して小さくない.なぜなら，後述するよらに内面プ ランジ研削の形状創成機構を合理的に解釈するためには，この 熱変形の膨張方向を明確に把握することが不可欠であり，さら に, 工作物の熱変形量が定量的に計測できてこそ, 高精度から 高能率な内面プランジ研削が達成可能となるからである.

従来, 平面研削之円筒外面研削に打ける工作物熱変形量 $d_{\theta \mathrm{w}}$ は砥石の実干渉深さを增加させる方向に機能していることか

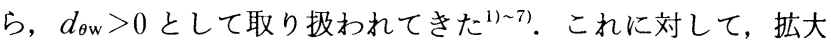
図 (a)に示すように内面プランジ研削では逆に砥石の実干渉深 さを減少させる方向へ作用しているため, 本論文では $d_{\theta \mathrm{w}}<0$ と定義する.

図 4 (a)に示す工作物熱変形量 $d_{\theta \mathrm{w}}(b)$ の絶対値は, 1 段プラ ンジ研削域で増加し，2段プランジ研削域とスパークアウト過 程ではその切り替え時点でそれぞれ変曲点をもちながら減少す る. また，幅方向 $b$ に対する変化から， $d_{\theta \mathrm{w}}(b)$ の絶対値は幅 中央部 $B / 2$ あるいはその近傍で最大となり，両端玉どその值 は小さいことがわかる．平面研削では加亡中の工作物形状が平 坦であっても，幅方向の各位置で不均一に分布する熱変形量の 収縮によって, 冷却後の表面形状が中凹状になることはよく知 


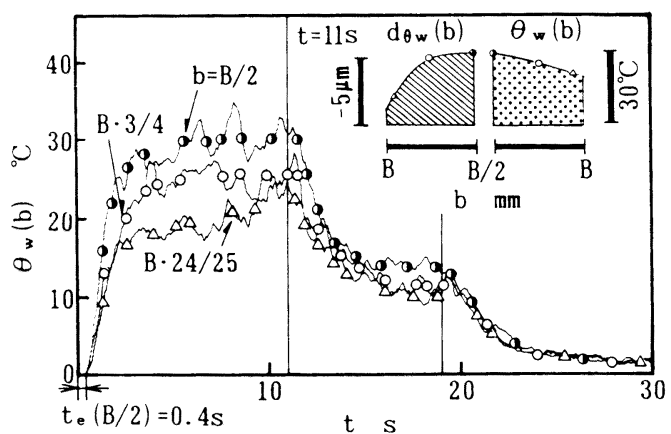

Fig. 5 Variation of workpiece surface iemperature $\theta_{\mathrm{w}}(b)$

られている ${ }^{1) \sim 5)}$ ，ところが，内面プランジ研削では工作物の熱 変形方向が異なるため, 平面研削の形状創成機構とは正反対の 現象が発生していることになる。すなわち，図中の実測面で示 す冷却後の工作物断面形状から $d_{\theta \mathrm{w}}(b)$ の熱変形分布を考慮し て, 研削中の断面形状を予測すると，その形状は極度の中山状 を呈し，平坦ではない。つまり，内面プランジ研削では幅中央 部近傍で最大となる工作物熱変形量 $d_{\theta \mathrm{w}}(b)$ が収縮することに よって, 研削中に創成されている顕著な中叫形状が逆に平坦化 の方向に改善され，この熱変形量 $d_{\theta \mathrm{w}}(b)$ の收縮過程で修正し きれない量が冷却後の中田量 $\delta$ として残存するのだ，と判断 できる.

ただし，本実験で測定している工作物熱変形量 $d_{\theta \mathrm{w}}(b)$ は， 工作物全体の昇温によって発生する熱膨張量であり，砥石との 干渉域に打ける工作物の局所熱変形量4)51ではない。この局所 熱変形によっても，中回量 $\delta$ は影響を当然受けているものと 推測されるが，本論文ではそこまでの定量的解析は実行してい ない，もっとも，平面研削では平坦な工作物表面が熱変形のた めに中凹状に変化するのに対して，内面プランジ研削では加工 中に創成される顕著な中凹量が熱変形の収縮時に減少し，最終 的に改善された中田量が工作物に残存するのだと主張している メカニズムは本質的には間違っていないものと思われる.

図 4 (b) にこの中叫量 $\delta$ の変化を示す. $\delta$ の変化過程が工作 物熱変形量 $d_{\theta \mathrm{w}}(b)$ の挙動と定性的には同様であることから も, 中凹量 $\delta$ が前述の工作物の熱収縮過程に連動して形成さ れていることは明らかである.

図 5 に工作物の表面温度 $\theta_{\mathrm{w}}(b)$ の変化を示す。図 2 (b)で示 した接触式温度センサに複数個の熱電対を組込んで 3 箇所の $\theta_{\mathrm{w}}(b)$ を同時に計測した．研削時間 $t$ に対する $\theta_{\mathrm{w}}(b)$ の変化 は定性的には図 4 (a)の工作物熱变形量 $d_{\theta \mathrm{w}}(b)$ の变化と同じで あるが，図中の比較図からも理解できるように，表面温度 $\theta_{\mathrm{w}}(b)$ と工作物熱変形量 $d_{\theta \mathrm{w}}(b)$ の変化傾向は定量的には一致 していない，ただし， $d_{\theta \mathrm{w}}(b)$ が工作物端で小さくなる理由は， その位置での $\theta_{\mathrm{w}}(b)$ が低いためであることは，少なくともこ の図より読み取れるであろう。

以上，工作物の熱変形分布とその収縮過程の観点から，研削 後の工作物に中山形状が残留する機構を解明した。では，なぜ 研削中の工作物は図 4 （a) に示すほど極度の中凹状に創成され ているのか?, といら根本的な疑問が新たに提起されてくる. 次に砥石の熱変形挙動からこれを考察しょう。

図 6 に砥石熱变形量 $d_{\theta \mathrm{s}}(b)$ の測定例を示す。砥石の急速後 退直前の砥石面プロフィルをアクリル板に転写し，別途，冷却 後のそれをアクリル板のみを削る状態で転写して，工作物と干 涉していない両端部を基準に両者を比較すれば，砥石面のプロ

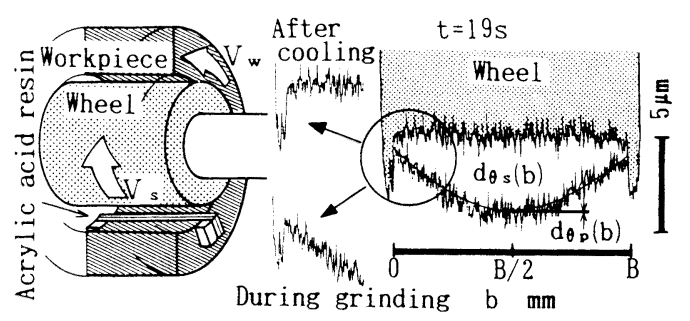

Fig. 6 Measuring method of thermal deformation of wheel $d_{\theta \mathrm{s}}(b)$

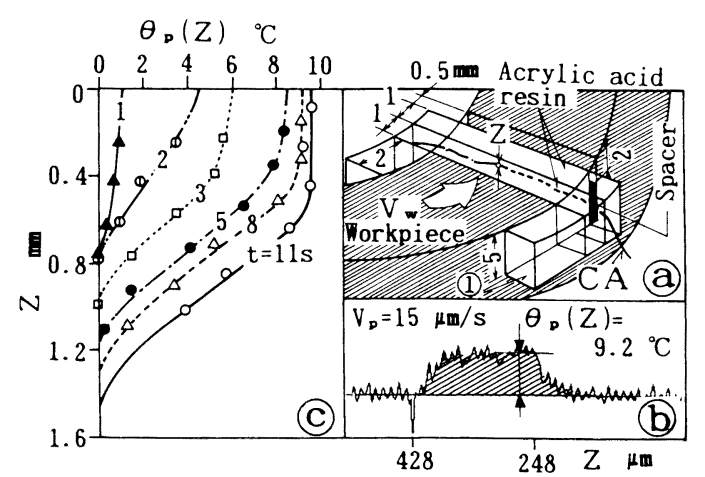

Fig. 7 Distribution of temperature of acrylic acid resin $\theta_{\mathrm{p}}(Z)$

フィル変化すなわち砥石熱変形量 $d_{\theta \mathrm{S}}(b)$ が検出できる.ただ し，研削熱はアクリル板にも伝達しているので，アクリル板の 熱変形量 $d_{\theta \mathrm{p}}(b)$ を前もって差し引いて打くことが必要となる.

そこで，図７（a)に示すCA 熱電対埋込み法ならびに図 2 (a) で試作したスリップリングを用いてアクリル板の深さ方向 $Z$ の温度分布 $\theta_{\mathrm{p}}(Z)$ を検出した. 図 (bに $\theta_{\mathrm{p}}(Z)$ の測定例を示 す。本実験で挿入したアクリル板の場合，板厚が $2 \mathrm{~mm}$ と薄い こと, ならびに加工面から $2 \mathrm{~mm}$ の深さまで空隙が形成される ように固定用のスペイサーで調整しているため，アクリル板の 円周方向の熱膨張量は拘束されていないものと判断できる. 従って，アクリル板の熱変形量 $d_{\theta \mathrm{p}}(b)$ は砥石面方向へ自由膨 張していると考光, 図 (C)の温度分布 $\theta_{\mathrm{p}}(Z)$ と線膨張係数 ${ }^{14)}$ $\left(=5.0 \times 10^{-5}{ }^{\circ} \mathrm{C}^{-1}\right)$ との積で $d_{\theta \mathrm{p}}(b)$ を決定した.

な技，図 (a)中のアクリル板 (1) は, 図 4 (b)に示す中山量 $\delta$ の水平基準面を測定用に創成するためのものである.

図 8 (b)にアクリル板の熱変形量 $d_{\theta \mathrm{p}}(B / 2)$ の変化を示す. ア クリル板の熱変形量も幅中央部 $B / 2$ で最大值をとっており, 幅方向 $b$ の全データを掲載すると煩雑になるので，図では $B /$ 2 に拈けるアクリル板の熱変形量 $d_{\theta \mathrm{p}}(B / 2)$ だけを代表させて

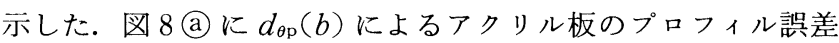
を差し引いて, 最終的に得られた砥石熱变形量 $d_{\theta \mathrm{S}}(b)$ を示す. この $d_{\theta \mathrm{s}}(b)$ の変化挙動から, 図 4 (a)で提起された工作物形状 が極度の中凹状に創成される原因は，砥石面プロフィルがほぼ 同形状に熱膨張しているためであると理解でさる．すなわち， 砥石熱変形量 $d_{\theta \mathrm{S}}(b)$ が幅中央部近傍で常に最大値を示してい る事実ならびに，図中のタイコ状の砥石面プロフィルと工作物 熱変形量 $d_{\theta \mathrm{w}}(b)$ を考慮した研削中の断面形状とが定量的に一 致している事例とから，このことは了解されるであろう.

図 8 (c) に示寸砥石摩耗量 $d_{0}(b)$ の变化と図 (a)の砥石熱変形 量 $d_{\theta \mathrm{s}}(b)$ とを比較すると, 本実験条件の内面プランジ研削で は, 研削過程のほとんどの領域において, 砥石中央部近傍の $d_{\theta \mathrm{S}}(b)$ は $d_{0}(b)$ よりも大きい,つまり, 摩耗していない砥石 面両端よりもさらに突出した位置で，タイコ状に熱膨張した砥 


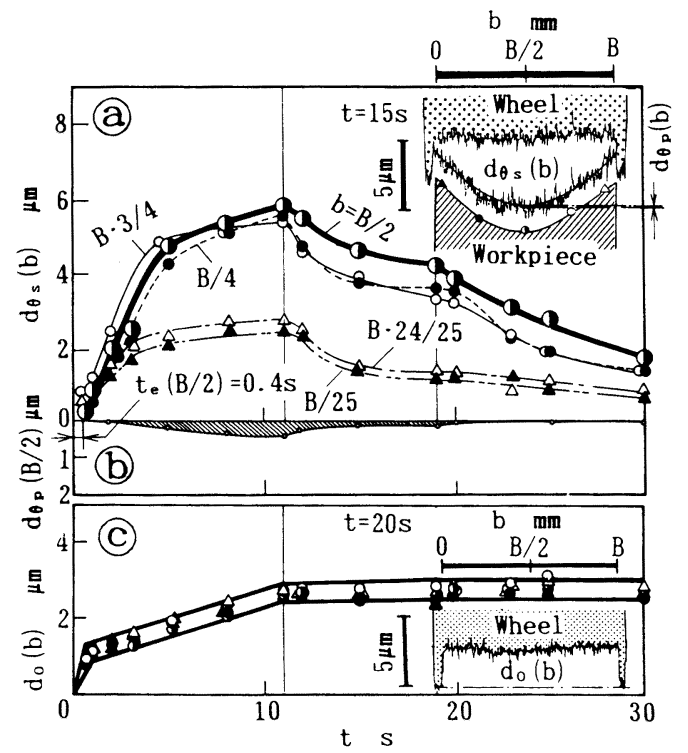

Fig. 8 Variations of thermal deformation of wheel $d_{\theta \mathrm{s}}(b)$ and wheel wear $d_{0}(b)$

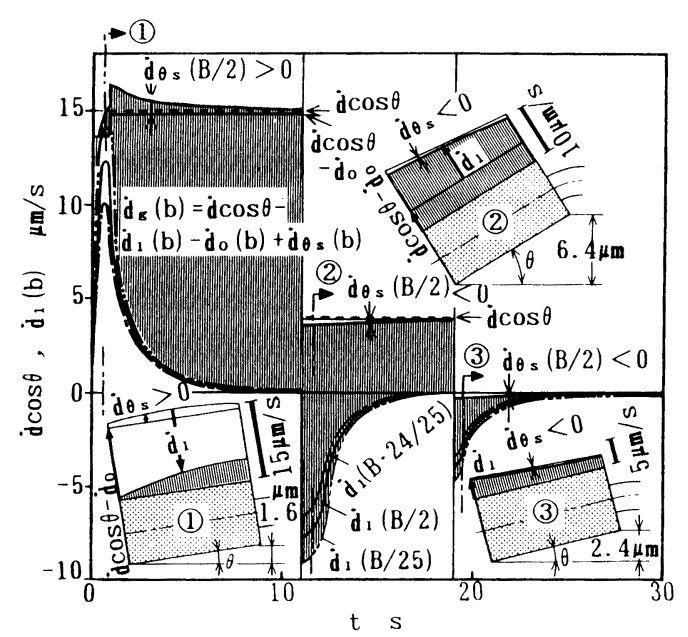

Fig. 9 Variation of actual infeed speed $\dot{\boldsymbol{d}}_{\boldsymbol{B}}(b)$ under considering residual stock rate $\dot{\boldsymbol{d}}_{1}(b)$ and thermal deformation rate of wheel $\dot{\boldsymbol{d}}_{\theta \mathrm{s}}(b)$

石中央部が工作物と干渉していることになる，本実験と同種の 結合剂であるビトリファイド砥石を用いて円筒外面研削の砥石

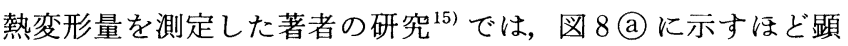
著な砥石熱変形量は観察されていない.いま, 円筒外面研削で の標準的な $\phi 400 \mathrm{~mm}$ の砥石と本実験の $\phi 21 \mathrm{~mm}$ の内面研削 砥石において, 加工条件の研削速度と工作物幅ならびに研削主 分力の出力値が同等であると仮定すると, 単位面積当たりの発 生研削熱すなわち研削熱流量は内面研削砥石の方が 19 倍大き くなる.つまり，このことからビトリファイド砥石の内面プラ ンジ研削ではその極めて過酷な熱的環境のために, 図 8 （a)に 示す顕著な砥石熱变形が発生していても不思議ではないことが わかる.

\section{4. 熱変形挙動を考慮した内面プランジ研削 の形状創成機構}

図 9 は，次式で与兄られる砥石作用面の実切込み速度 $\dot{d}_{\mathrm{g}}(b)$ を検討したものである.

$$
\dot{\boldsymbol{d}}_{\mathrm{g}}(b)=\dot{\boldsymbol{d}} \cos \theta-\dot{\boldsymbol{d}}_{1}(b)-\dot{\boldsymbol{d}}_{0}(b)+\dot{\boldsymbol{d}}_{\theta \mathrm{s}}(b)
$$

ここで図中の $\dot{\boldsymbol{d}} \cos \theta$ は, $\dot{\boldsymbol{d}}$ をホイールヘッドのプランジ速

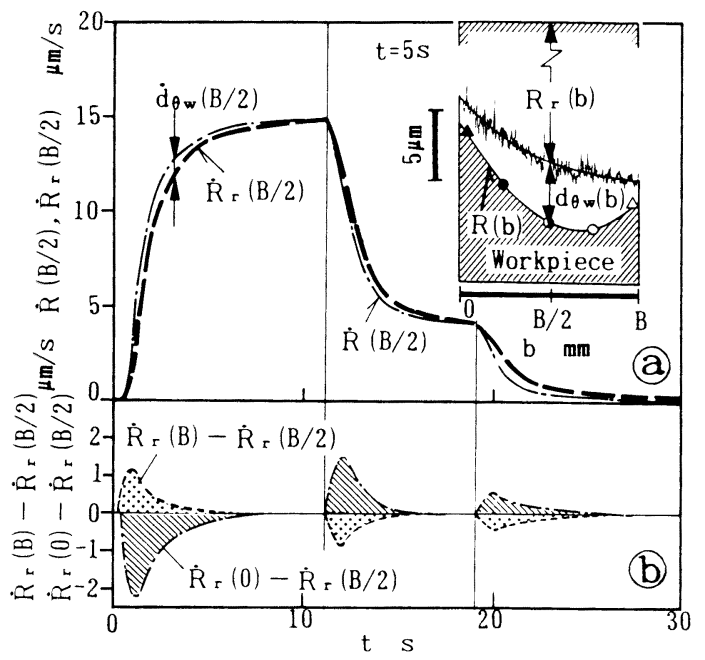

Fig. 10 Variation of actual size generation rate $\dot{R}_{\mathrm{r}}(b)$

度， $\theta$ を砥石軸のたわみ角と定義したときの，砥石作用面の垂 直方向に打けるプランジ速度成分である.この $\dot{\boldsymbol{d}} \cos \theta$ から砥 石軸と主軸のたわみ速度 $\dot{\boldsymbol{d}}_{1}(b)$ 打よび砥石摩耗速度 $\dot{\boldsymbol{d}}_{0}(b)$ を 差し引き，さらに，切込久速度を增加させる方向に作用する砥 石熱変形速度 $\dot{\boldsymbol{d}}_{\theta \mathrm{S}}(b)$ を加算した値が，式（1）の砥石作用面の 実切込久速度 $\dot{\boldsymbol{d}}_{\mathrm{g}}(b)$ となる. 図 9 のハッチングで示す $\dot{\boldsymbol{d}}_{\mathrm{g}}(b)$ は，切込久過程の各段階に打いて幅方向に不均一に分布してい る. 例光ば，切込み初期 (1)の軸たわ久速度 $\dot{\boldsymbol{d}}_{1}(b)$ は図中の 3 本の曲線で示すように幅方向 $b$ で異なるため, $\dot{\boldsymbol{d}}_{\mathfrak{g}}(b)$ は砥石 先端から終端にかけて連続的に増加している. しかも, プラン シ速度成分 $\dot{\boldsymbol{d}} \cos \theta$ と砥石摩耗速度 $\dot{\boldsymbol{d}}_{0}(b)$ との差で与えられ る有効プランジ速度 $\left(\dot{\boldsymbol{d}} \cos \theta-\dot{\boldsymbol{d}}_{0}(b)\right)$ のほとんどが, この軸 たわみ速度 $\dot{\boldsymbol{d}}_{1}(b)$ に消費されてしまい, 砥石熱変形速度 $\dot{\boldsymbol{d}}_{\theta \mathrm{s}}$ （b）を加味しても実切込み速度 $\dot{\boldsymbol{d}}_{\mathbf{g}}(b)$ は非常に小さい.

一方，2段プランジ研削域 (2) とスパークアウト過程 (3) で は, 軸たわみ量 $d_{1}(b)$ の解放, 寸なわち $\dot{d}_{1}(b)<0$ として式 （1）に作用するので，(1)の場合とは逆に砥石先端ほど実切込み 速度 $\dot{\boldsymbol{d}}_{\mathrm{g}}(b)$ は大さい. この $\dot{\boldsymbol{d}}_{\mathrm{g}}(b)$ に対応して幅方向 $b$ の寸法 すなわ工作物形状が創成されることになる.

図 10 (a) に幅中央部 $B / 2$ に打ける実寸法生成速度 $\dot{R}_{\mathrm{r}}(B / 2)$ の变化を示す。前章で詳述したように内面プランジ研削では工 作物の熱膨張方向が平面研削や円筒外面研削の場合とは正反対 であるため，実寸法生成速度に及ぼす工作物熱変形速度の影響 も逆となる.すなわち，1段プランジ研削域では砥石面から離 れる方向に熱膨張するので, 定寸装置で検出される公称寸法生 成速度 $\dot{R}(B / 2)$ よりも熱変形速度 $\dot{\boldsymbol{d}}_{\theta \mathrm{w}}(B / 2)$ の量だけ小さい 速度 $\dot{R}_{\mathrm{r}}(B / 2)$ で专寸法が創成される. 一方, 2 段目とスパー クアウト過程では熱変形量が砥石面に近付く方向へ収縮する結 果, その関係は逆転して, $\dot{R}_{\mathrm{r}}(B / 2)>\dot{R}(B / 2)$ となる. また, 図中の工作物の実測断面からもわかるように, 内面プランジ研 削では砥石軸の傾斜によるテーパと工作物熱变形量 $d_{\theta \mathrm{w}}(b)$ に よる中凹形状の重畳した形態で研削が進行している．つまり, 前述の実切込及速度 $\dot{\boldsymbol{d}}_{\mathrm{g}}(b)$ の変化に対応して, 工作物幅の各 位置 $b$ で実寸法生成速度 $\dot{R}_{\mathrm{r}}(b)$ が異なっていることになる. 例えば，図(b) の 1 段プランジ研削域では砥石末端 B の近傍で 最大の実寸法生成速度が発生して括り，プランジ速度 $V_{\mathrm{p} 1}=15$ $\mu \mathrm{m} / \mathrm{s}$ に対して両端での実寸法生成速度の差が最大で $3.4 \mu \mathrm{m} /$ $\mathrm{s}$, 割合にして $22 \%$ にも達している. 従って, 内面プランジ研 削では砥石軸方向に不均一に分布する実切込み速度 $\dot{\boldsymbol{d}}_{\mathrm{g}}(b)$ と 


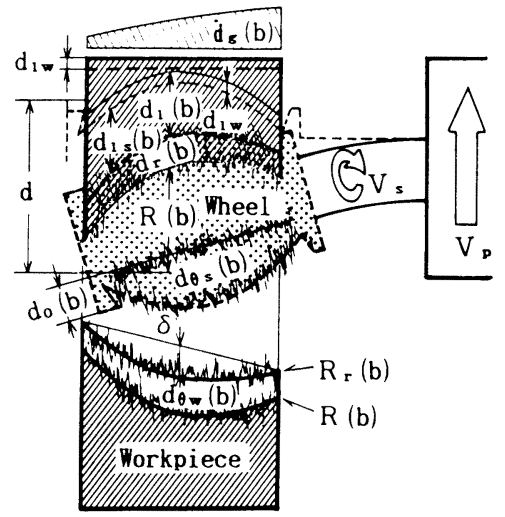

Fig. 11 Form generation mechanism in internal plunge grinding

幅中央部で最大となる工作物熱変形速度 $\dot{\boldsymbol{d}}_{\theta \mathrm{w}}(b)$ のために，幅 方向の各位置で連続的に変化するプランジ研削過程が進行して いると考えるべきである.

また，この実寸法生成速度 $\dot{R}_{\mathrm{r}}(b)$ の変化挙動のため, 砥石 摩耗量 $d_{0}(b)$ 女厳密な意味では砥石面の各位置 $b$ で同じ值と はならない。しかし，前揭の図 8 (c)に打ける $d_{0}(b)$ の解析で は, この $\dot{R}_{\mathrm{r}}(b)$ の差による砫不摩耗量 $d_{0}(b)$ の変動と測定 データのバラッキとを明確に分離できなかったので，一応の目 安として実寸法生成速度 $\dot{R}_{\mathrm{r}}(b)$ の影響の範囲を平行線で示し た.

図 11 で, 内面プランジ研削の形状創成機構を砥石と工作物 の熱変形挙動の観点から総括的に論述してみる. まず，内面プ ランジ研削では，主軸扣よび砥石軸が研削背分力によって $d_{1 \mathrm{w}}, d_{\mathrm{Is}}(b)$ だけそれぞれ変位し，これらの和で与えられる軸 たわ久量 $d_{1}(b)$ は砥石面の幅方向で不均一に分布している. その結果, 実切込み速度 $\dot{\boldsymbol{d}}_{\mathrm{g}}(b)$ は砥石面幅で連続的に変化す るようになる. 一方, 砥石摩耗量 $d_{0}(b)$ はほぼ均一に進行し ているが, 過酷な熱的環境のため砥石熱変形量 $d_{\theta \mathrm{S}}(b)$ は幅中 央部で顕著に膨張し，その結果，砥石面形状はタイコ状に熱変 形する. このタイコ状の砥石面によって, 工作物断面が $R(b)$ 曲線で示寸極度の中形状に創成されるのである．ただし，工 作物は砥石面から離れる方向へ $d_{\theta \mathrm{w}}(b)$ だけ熱変形しているの で，この時点で研削を中断すると幅中央部近傍で最大分布を示 寸工作物熱変形量 $d_{\theta \mathrm{w}}(b)$ が収縮する過程で, 極度の中山形状 は緩和され，熱収縮過程で修正しきれない量が中凹量 $\delta$ とし て残存する.さらに，これらの形状創成機構は軸のたわみに よって傾斜したタイコ形状の砥石面で遂行されているため, 最 終的に中山状のテーパが专工作物断面 $R_{\mathrm{r}}(b)$ の位置に創成さ れることになる。

\section{5. 結 論}

本論文で得られた主要な結論は以下のとおりである.

（1）研削中と冷却後の砥石面プロフィルをアクリル板転写 法で比較し，さらにアクリル板自身の熱変形量を考慮し て，内面プランジ研削の砥石熱変形量を検出した。幅中央 部近傍で最大となる砥石熱変形のため, 砥石面はタイコ形 状に膨張し，その結果，研削中の工作物は極度の中山状に
創成される。

（2）ホイールヘッド急速後退法で計測した内面プランジ研 削の工作物熱変形量は, 平面研削之円筒外面研削の場合之 は全く正反対に，工作物の内径を増加させる方向，すなわ ち砥石面から離れる方向へ膨張することを確認した。

（3）工作物熱変形量の絶対值は幅中央部近傍で最大となり, その両端で小さくなる分布形態を示す．この工作物の熱変 形量が収縮する過程で，研削中に創成されている極度の中 凹形状 (結論 (1)) は平坦化の方向に改善され, 修正しき れない量が冷却後の中山量として残存する.

（4） 内面プランジ研削に打ける実切込み速度と工作物熱変 形速度は幅方向に不均一に分布している，そのため，本実 験条件の場合, 実寸法生成速度も工作物両端で最大 $22 \%$ も異なって扣り，このことから，工作物幅の各位置で連続 的に变化するプランジ研削過程が進行していることにな る.

（5）内面プランジ研削の形状創成機構は, 主軸と砥石軸の 傾斜によって創成されるテーパ状の工作物断面に，幅方向 に分布する砥石と工作物の熱変形量に起因して形成される 中凹形状が重畳した形態で進行している.

$$
\text { 謝辞 }
$$

本研究の遂行にあたり，試験機ならびに試料をご提供をいた だいたトーヨーエイテック株式会社に厚く謝意を表します。

\section{参 考 文 献}

1）中野嘉邦, 太田勝彦：平面研削中の工作物の熱変形と研削後の形状 䛣差一平面研削に打ける工作物の熱変形の研究 (第 1 報), 精密機 械, 39, 2 (1973) 225 .

2) 中野嘉邦, 太田勝彦: 平面研削中の工作物の定常熱変形の解析 ——平面研削に㧊ける工作物の熱変形の研究（第 2 報)，精密機械， 41, 4 (1975) 364.

3）横山和宏, 一宮亮一：平面研削に怙ける加工物の熱変形, 精密機械, 42, 10 (1976) 967 .

4）奥山繁樹，西原徳彦，河村末久：平面研削に抢ける形状精度に関す る研究——研削熱による曲げ变形の影響，精密工学会誌，54，8 (1988) 1496.

5）西原徳彦，奥山繁樹，河村末久：平面研削に抢ける形状精度に関す る研究——プランジ研削に打ける形状の創成過程，精密工学会誌， 57, 9 (1991) 1597

6）中島利勝，塚本真也，湯川知厚：極薄板の平面研削に招ける寸法・形 状生成機構の研究, 精密工学会誌, 58, 8 （1992） 1369.

7） 中島利勝, 塚本真也, 原田 真：研削熱による变形が寸法生成過程 に及注す影響の研究，精密機械，51，8（1985）1588。

8） 中原一郎：材料力学, 下巻, 養賢堂, (1993) 100.

9）金内忠彦，鍵和田忠男：研削に括ける工具・被削材の寸法挙動（第 1 報）一一砥石温度分布之熱膨張・摩耗, 日本機械学会論文集（C 編）, 51, 467 (1985) 1844.

10）鍵和田忠男，西村由明，金内忠彦：非接触走査形半径差比較システ ムによる砈石寸法挙動の自動計測, 日本機械学会論文集 (C 編), 58, 546 (1992) 607.

11）中島利勝, 塚本真也, 佐藤一伸：研削加工に扣ける砥石の熱変形速 度の研究, 精密工学会誌, 55,2 (1989) 354.

12）中島利勝，塚本真也，トーヨーエイテック（株）：研削装置，公開特 許公報, 特開平 6-246632（1994）。

13）中島利勝, 塚本真也, 吉川満雄：水溶性研削油剂の作用に関する研 削（第 3 報）一一界面活性剤の泠却性抢よび潤滑性と研削結果, 精 密工学会誌, 54, 2 (1988) 414.

14）日本化学会：化学便覧応用編，改定 3 版，丸善，（1980） 809 .

15) T. Nakajima and S. Tsukamoto : Effects of Grinding Heat upon Grinding Process, SME Techinical Paper, (1990) MR 90-517. 